\title{
MOTYWIKA TOŻSAMOŚCI W TEKSTACH KRZYSZTOFA VARGI O TEMATYCE WËGIERSKIEJ
}

\section{NIE TYLKO GULASZ Z TURULA}

Krzysztof Varga stał się szeroko znany na Węgrzech dzięki głośnemu za sprawą skrajnych opinii Gulaszowi z turula, który wywołał skandal już samym tytułem. Rzadko jednak wspomina się, że tematyka węgierska pojawia się w twórczości Vargi wcześniej. Jego pierwsza wydana na Węgrzech książka, której poświęcono stosunkowo niewiele uwagi, w jednym tomie zawierała dwie krótkie powieści: Tequile i Bildungsroman ${ }^{1}$. Tematyka węgierska pojawia się w tej drugiej, w której pisarz prezentuje równie krytyczny stosunek do Węgrów, co w swoich późniejszych tekstach. Trudna do rozwikłania ze względu na typowy dla autora styl narracji akcja skupia się wokół podróży Kristófa do Budapesztu. Postać ta może być postrzegana jednocześnie jako alter ego autora i narratora oraz jego starzejącego się ojca, Béli. Konfrontacja z własnym pochodzeniem, nostalgiczne poszukiwania korzeni mieszają się z rzeczywistą i asocjacyjną podróżą przez wspomnienia. Próba ta jednak kończy się nieuchronną porażką lub rozczarowaniem. W wywiadzie udzielonym węgierskiemu czasopismu literackiemu „Élet és Irodalom” [Życie i Literatura] Varga tak opowiada o powstaniu tekstu: „Mogłem ostatecznie załatwić również kilka własnych spraw uczuciowych, ale nie wiem, czy wyrzuciłem

Mgr VIKTÓRIA VAS - Wydział Nauk Humanistycznych Katolickiego Uniwersytetu im. Pétera Pázmánya w Budapeszcie; e-mail: vas.viktoria@yahoo.com

${ }^{1}$ K. VARGA, Fejlödésregény, Tequila, Dunakeszi 2008. 
z siebie wszystko" "2. Później wspomina także, że w bliskiej przyszłości najchętniej napisałby przewodnik po Węgrzech. (Co tak właściwie udało mu się zrealizować za sprawą Gulaszu z turula, choć nie do końca w formie przewodnika.)

W przedmowie do węgierskiego wydania Gulaszu z turula ${ }^{3}$ czytamy, że książka ta powstała przede wszystkim dla polskich czytelników, by skonfrontowali się oni ze swoim wyidealizowanym i przestarzałym obrazem węgierskości. Varga dekonstruuje symbole wizerunku Węgier i zwraca ich uwagę na całkowicie inny obraz Węgier. Odkłada na bok tradycyjną przyjaźń polsko-węgierską, a w jej miejsce proponuje obraz powstały na podstawie subiektywnych doświadczeń, który mimo wszystko, a może właśnie przez to zdradza o wiele silniejsze powiązania.

W jego tekstach motywy, symbole i stereotypy uważane za narodowe staja się źródłem humoru i ironii. Najbardziej dobitnym przykładem zamiaru dekonstrukcji symbolu narodowego jest sposób potraktowania mitologicznego ptaka Węgrów. Prawdopodobnie właśnie to było jednym z głównych powodów wywołanego przez książkę skandalu. Symbol turula Varga przedstawia jako uosobienie ciężkiej węgierskiej nostalgii. Jak sam pisze: „Turul, dziwne skrzyżowanie orła z gęsią, jest połączoną personifikacją węgierskich marzeń i kompleksów"4. Rusza na symboliczne ,polowanie na turula" i próbuje wytropić, w jakich punktach kraju i gdzie dokładnie możemy natknąć się na ślady tego skrzydlatego bohatera węgierskiej mitologii. Następnie dokonuje on kategoryzacji tych pomników: „turul bojowy $-\mathrm{z}$ rozdziawionym dziobem, mieczem $\mathrm{w}$ szponach i szeroko rozłożonymi skrzydłami (zamek w Budzie, XII dzielnica, Tatabánya); turul przejściowy - nie wiadomo, czy właśnie wznosi się do lotu, czy ląduje, mógłby szerzej rozwinąć skrzydła, ale nie może się zdecydować (turul przed dworcem kolejowym w Gyốr); turul wstydliwy - siedzący skromnie jak kura na grzędzie, z nieśmiało zwiniętymi skrzydłami i zamkniętym dziobem (obsrany przez gołębie turul na bramie w Sopron, kamienica na Tátra utca w Budapeszcie, wejście do banku OTP w Egerze)",

Krytyczny ton Vargi wynika z przyjętego punktu widzenia i roli narratora. Pisarz pokazuje, co widzi obcy, który przybywa na Węgry i nie może się odnaleźć w świecie miejscowych kodów kulturowych. Rzeczywistość ogląda-

\footnotetext{
${ }^{2}$ G. KereszTes, Mi legyen az ulánusok helyett?, „Élet és Irodalom” 2005, nr 11, s. 7.

${ }^{3}$ K. VARGA, Turulpörkölt, Budapeszt 2010, s. 5.

${ }^{4}$ K. VARGA, Gulasz z turula, Wołowiec 2008, s. 11.

${ }^{5}$ Tamże, s. 34-35.
} 
na jest z perspektywy osoby, która ma do dyspozycji tylko własne doświadczenia i ze zbioru przeróżnych informacji, wrażeń i bodźców musi stworzyć własny obraz Węgier. A przeżycia te są siłą rzeczy subiektywne. Dlatego też błędne wydaje się krytyczne podejście wyrażane w tonie osoby obrażonej, która wymienia domniemane lub rzeczywiste błędy merytoryczne, demonstrując jednocześnie moralną przewagę nad autorem ${ }^{6}$. Należy natomiast przyznać rację krytykom co do wyolbrzymień. Książka rzeczywiście jest ich pełna, jednak wyolbrzymienia te nie są celem samym w sobie. Mają one swoja funkcję: wzmagają wewnętrzne napięcie w tekście, wynikające $\mathrm{z}$ tego, że narrator patrzy z perspektywy „obcego”, a jednocześnie jest w posiadaniu informacji, które dostępne są tylko dla „wtajemniczonych”. Cechą charakterystyczną narratora jest to, że jednocześnie pozostaje obserwatorem postronnym i wtajemniczonym. Pokazuje Węgry z perspektywy obcego, ale oprowadza po tym świecie i tłumaczy pewne zjawiska z pewnością kogoś, kto jest u siebie. Wskazują na to również rozdziały książki, których tytuły łączą w sobie nazwę węgierskiej potrawy i nazwisko ważnej postaci z historii lub świata polityki. Spotykamy się z takimi tytułami, jak: Paprykarz z Kádára, Pieczeń z Horthyego, Zupa z Rákosiego, Pörkölt z Bulcsú i Lehela, Salami ze Świętego Stefana, Leczo z Gyurcsánya i Orbána, Smalec z Kossutha, Kotlet z Árpáda.

Varga jest przewodnikiem, który rzeczywiście odwiedził opisywane przez siebie miejsca. Wszystko, na temat czego wyraża opinię, opiera się na jego własnych doświadczeniach. Świadomie trzyma się z daleka od oklepanych punktów turystycznych, bądź wspomina je właśnie w ramach tej kategorii jakościowej. Bardziej lubi codzienny Budapeszt zarysowujący się wokół świata małych knajpek i jadłodajni. Wymienia z nazwy ulice i miejsca, restauracje, targowiska, sklepy mięsne. Historię miasta opisaną przez Vargę zdominował gatunek określany jako legenda miejska, plotka, który z natury rzeczy należy nie do świata turystów, lecz miejscowych.

Wspomnieć należy o jeszcze jednym tekście związanym z Węgrami. To dziennik Vargi z Peczu zatytułowany Pécs, ahol élnék [Pecz, gdzie mógłbym mieszkać], który ukazał się w antologii wydanej w ramach programu „Pecz Europejską Stolicą Kultury”. Podczas Writers in Residence Program wraz $\mathrm{z}$ wieloma innymi współczesnymi pisarzami z Europy spędził miesiąc w Peczu, gdzie w trakcie pobytu autorzy pisali o swoich wrażeniach i zapiski te

\footnotetext{
${ }^{6}$ P. PÁtrovics, Magyarország-képek a mai Lengyelországban, w: Kutatási füzetek 16, red.
} O. Mária, Pécs 2010, s. 153-172. 
ukazały się następnie w formie antologii. Już sam tytuł może wskazywać i rzeczywiście tak jest - że to najmniej krytyczny tekst Vargi dotyczący Węgier. Autor stwierdza bowiem, że choć podoba mu się wielkomiejskie tempo życia w Warszawie, chętnie mieszkałby w Peczu. W interpretacji Lajosa Pálfalviego oznacza to, że „wykształciło się już w nim ego, które czuje się na Węgrzech jak w domu"" .

W tych trzech dziełach o tematyce węgierskiej wyraźnie wyczuwalne jest odmienne posługiwanie się obrazem węgierskości. W przeciwieństwie do wzbierającego potoku wspomnień w Bildungsroman, w Gulaszu z turula spotykamy się z o wiele bardziej przejrzystą, można by powiedzieć: bardziej świadomą kompozycją. Pojawiają się powracające elementy, jak na przykład wspomnienie podróży do Dánszentmiklós, ale za każdym razem mają one inną funkcję i wpisują się w inne koncepcje. Jednocześnie wyczuwalne jest również i to, że tematyka ta staje się dla autora coraz ważniejsza, wielokrotnie z niej czerpie i robi to coraz bardziej świadomie.

\section{SINDBAD WĘDRUJE DALEJ}

Na ważną rolę motywu Sindbada wskazuje fakt, że w trzech spośród pierwszych czterech książek o tematyce węgierskiej pojawia się postać tego legendarnego bohatera dzieł Gyuli Krúdyego (i Sándora Máraiego), czyli mamy do czynienia z powracającym i nieustannie kształtującym się motywem ${ }^{8}$. Można

${ }^{7}$ L. PÁLfalvi, Krzysztof Varga és a magyar-lengyel haikio-élmény, „Kalligram” 2012, nr 9, s. 89.

${ }^{8}$ W twórczości Krúdyego postać Sindbada pojawia się w czterech cyklach opowiadań, dwóch powieściach i dziewiętnastu innych opowiadaniach. Tajemniczy główny bohater noszący imię żeglarza z Baśni tysiaca i jednej nocy pojawił się po raz pierwszy w wydanym w 1911 roku cyklu Szindbád ifjúsága [Młodość Sindbada], tom ten z nieco zmienioną treścią ponownie ujrzał światło dzienne w 1925 roku. W 1912 roku ukazały się Szindbád utazásai [Podróze Sindbada], a w 1916 Szindbád: A feltámadás [Sindbad: zmartwychwstanie]. Ostatnim cyklem opowiadań było Szindbád megtérése [Nawrócenie Sindbada] z 1925 roku. Wyboru tekstów do wspomnianych wyżej tomów dokonał sam Krúdy, w przeciwieństwie do zbioru opowiadań Szindbád [Sindbad], a później Újabb Szindbád-történetek [Nowe opowieści o Sindbadzie], które powstały pod redakcją Sándora Kozocsy i zawierają opowiadania o Sindbadzie, które Krúdy świadomie pominął we wcześniejszych cyklach. Z tematyką Sindbada wiążą się jeszcze dwie powieści: Francia kastély [Francuski zamek] (1912) i Purgatórium [Czyściec] (1934). Po ostatnim zbiorze opowiadań ukazało się jeszcze 19 opowieści o Sindbadzie. W tym świetle wyraźnie widać, dlaczego Gábor Bezeczky pisze, że nie można analizować Sindbada w jednolity sposób, bowiem tak właściwie nie istnieje jeden zbiorczy tom pod tytułem Sindbad. A przynajmniej nie ma zbioru opowiadań, który Krúdy stworzyłby w takiej formie i pod takim 
się jednak zgodzić, że dziennik z Peczu ze względu na okoliczności powstania $\mathrm{z}$ tego punktu widzenia nie ma może takiego znaczenia. $\mathrm{Z}$ utworów tych wyraźnie zarysowuje się odmienny niż u czytelników węgierskich proces zapoznawania się z różnymi warstwami tego motywu, który wskazuje zarazem na to, że autor świadomie zagłębia się w tym temacie. Początkowo Sindbad pojawia się w tekstach Vargi za pośrednictwem filmu Zoltána Huszárika. Zatem po raz pierwszy spotyka się z nim nie bezpośrednio w tekstach Krúdyego, lecz poprzez pewną interpretację. W ten oto sposób już od samego początku świadomy jest paraleli istniejącej pomiędzy Krúdym-pisarzem a bohaterem jego dzieł Sindbadem ${ }^{9}$. Wkrótce po powstaniu filmu Huszárika krytycy pisali o reżyserze, że poprzez obraz potrafił zrealizować to, co u Krúdyego pojawia się za pośrednictwem języka, czyli charakterystyczny styl Krúdyego ${ }^{10}$. Varga ewidentnie z pełną świadomością odszyfrowuje warstwy znaczeniowe tworzące ten motyw. W swoim opowiadaniu o Sindbadzie nawiązuje do powieści Sándora Máraiego Sindbad powraca do domu ${ }^{11}$, co sta-

tytułem (patrz G. BEZECZKY, Végső búcsú Szindbádtól (1957-2002), „Literatura” 2002, nr 3, s. 286). Opowiadania o Sindbadzie powstawały cały czas na przestrzeni dwudziestu lat i prawdopodobnie wykazują większe podobieństwo z innymi dziełami Krúdyego powstałymi w tym samym okresie, niż ze sobą nawzajem, łączy je bowiem tylko postać Sindbada, dlatego też kolejność ich czytania może być dowolna. Według Györgya Bodnára cykl opowiadań o Sindbadzie może być czytany nawet jako powieść: byłaby to powieść statyczna, czy też współczesna powieść pikaryjska (patrz Gy. BODNÁR, A „mese”, a novellaciklus és a Szindbád, „Literatura” 1986, nr 1-2, s. 79).

${ }^{9}$ Od samego początku krytyka utożsamiała Krúdyego i Sindbada, a opinię tę dodatkowo umocniła powieść Máraiego Sindbad powraca do domu. Według Anny Fábri: „Postać Sindbada od początku do końca jest wyrażeniem poglądów autora: całościową opinią na temat możliwości życiowych na prowincji, codzienności, ograniczeń w życiu ludzkim oraz uroku walczącej z tym wszystkim fantazji człowieka, w tym również poezji” (A. FÁBRI, Ciprus és jegenye, Budapeszt 1978, s. 55).

${ }^{10}$ P. NAGY, Huszárik Zoltán: Szinbád, „Filmvilág” 1971, nr 23, s. 1-4.

11 W 1940 roku ukazała się powieść Sándora Máraiego pt. Sindbad powraca do domu. Pokrótce mówiąc, akcja obejmuje ostatni dzień z życia bohatera powieści. Rano wyrusza on z Óbudy do miasta i po raz ostatni odwiedza miejsca, z którymi łączą go jakieś wspomnienia. Historia ta zawiera wiele faktów z życia Krúdyego, a wszystko napisane jest w typowym dla niego stylu. Jednocześnie jednak w scenie w kawiarni pojawiają się postaci z czasów Máraiego - a zatem pisarze współcześni nie Krúdyemu, lecz Máraiemu. Anna Fábri w swoim artykule nt. Krúdyego wykazuje, że niemal bez przerwy czynił literaturę bohaterką swoich dzieł (patrz A. FÁBRI, „Egykor regényhös voltam...”, Az irodalom kultusza Krúdy Gyula múveiben, „Holmi” 2000, nr 6, s. 652). W ten sposób literatura staje się przestrzenią do wspominania literatury. Tradycję tę kontynuuje zarówno powieść Máraiego, jak i teksty Vargi. Według Gergelya Angyalosiego, imitując styl Krúdyego Márai nie miał na celu chowania się za maską tego słynnego pisarza, ponieważ nie było ku temu żadnej potrzeby: w 1940 roku on sam był już 
nowi odwołanie opierające się już nie w przeważającej części na wizualnych, lecz rzeczywistych wrażeniach czytelniczych. Zarówno dzieła Krúdyego, jak i Maraiego dostępne są również w tłumaczeniu na język polski ${ }^{12}$.

W Bildungsroman Krúdy-Sindbad wspomniany jest dwa razy. Jego postać po raz pierwszy ukazuje się nam poprzez asocjację związaną z Wyspa Małgorzaty. Czytamy, że Gyula Krúdy mieszkał na Wyspie Małgorzaty w klasztorze, który już nie istnieje. „Wstawał codziennie o szóstej rano i w przeraźliwym zimnie klasztornej celi siadał do stołu, by zacząć pisać kolejną nowelę o wędrówkach metafizycznych Sindbada, podróżnika po cmentarzach i sypialniach byłych kochanek. Zapach perfum mieszał się z trupim oddechem, woń żywego, ciepłego ciała z odorem rozkładającego się w ruszającej się ruchami robaczkowymi ziemi"13. Następnie, wspominając film Huszárika, przechodzi do charakterystyki Sindbada i wcielającego się w jego rolę w filmie Zoltána Latinovitsa. W przypadku obu z nich pisze najpierw o ich śmierci, wspomina o nich w związku ze śmiercią i melancholią, wątek ten jednak nie wyróżnia się w kontekście dalszych części powieści. „Latinowits uciekający w Sindbadzie przed śmiercią. Ponoć włosy i paznokcie po śmierci wciąż rosną. Jak bardzo urosły wąsy Latinowitsa?"14. Później poświęca Sindbadowi więcej miejsca, przywołując sceny z filmu: legendarną scenę obiadu, podróże Sindbada, cmentarz i nazywane numerami postaci kobiece, które Sindbad zostawił. Motyw Sindbada pozornie wykorzystywany jest przez Vargę jedynie w celu wzmagania nostalgiczno-melancholijnego klimatu powieści.

W Gulaszu z turula Sindbad pojawia się przede wszystkim w nawiązaniu do filmu Zoltána Huszárika. Ponownie wspomniane zostają fragmenty filmu. W charakterystyce Krúdyego możemy przeczytać: „,naczelny sybaryta węgierskiej literatury”, o Sindbadzie natomiast: „,melancholijny playboy z czasów belle épo-

cieszącym się sukcesami i uznaniem twórcą. Jego zdaniem klucz do zrozumienia powieści kryje się w gatunku pastiszu. Poprzez językowy świat opowiadań o Sindbadzie Sándor Márai tworzy własną interpretację Krúdyego. Jednakże nie tylko brawurowo naśladuje jego styl, lecz również stawia znak równości pomiędzy Krúdym a Sindbadem. Márai z jednej strony jest w stanie uchwycić Krúdyego tylko na poziomie stylu, czyli niezupełnie w pełni, z drugiej jednak - ukształtowana przez niego postać Sindbada-Krúdyego wyraża jego własne idee i refleksje. Dlatego właśnie należy mówić o pastiszu manifestującym się w formie interpretacji, który tak naprawdę więcej mówi o Máraim niż o Krúdym (patrz G. ANGYALOSI, A pastiche mint interpretáció, „Literatura” 1986, nr 1-2, s. 103).

${ }^{12}$ S. MÁrAi, Sindbad powraca do domu, tłum. T. Worowska, Warszawa 2008; Gy. KrúDY, Sindbad, tłum. A. Nawrocki, Warszawa 1988; Gy. KRÚDY, Miasto uśpionych kobiet, tłum. E. Cygielska, T. Worowska, Warszawa 2019.

${ }^{13}$ K. VARGA, Bildungsroman, Warszawa 1997, s. 60.

14 Tamże, s. 61. 
$q u e^{" 15}$. Opis koncentruje się przede wszystkim na słynnej scenie ze szpikiem: „Z pewnością jest to najwybitniejsza w światowej kinematografii scena pokazująca jedzenie rosołu"16. Sindbada nazywa nawet wampirem emocjonalnym, który

w powierzchownych miłostkach szuka ukojenia swojego weltschmerzu, w jedzeniu znajduje chwilowe zaspokojenie głodu uczuć, w ciagłej podróży chce znaleźć ucieczkę przed śmiercią. Nie lubi „dzisiejszych czasów” i żyje wyłącznie wspomnieniem przeszłości, nie zgadzając się na przemijanie. Sentymentalne wspomnienie dawnych czasów, przywoływanie kobiet, które odeszły, które zostały porzucone, które się utopiły, rzuciły z okna, które w posiadanie wzięli nie mężczyźni, ale czerwie, jest niczym więcej jak tylko szczepionką przeciwko śmierci, w świadomość wstrzykuje się w niewielkich ilościach wirusa śmierci, aby nas na prawdziwą śmierć uodpornit ${ }^{17}$.

Obok wspomnianych wyżej dzieł, starzejącemu się Sindbadowi poświęcił całe opowiadanie o wymownym tytule Sindbad sie starzeje ${ }^{18}$. Varga umieszcza Sindbada w dzisiejszym Budapeszcie. Akcja opowiadania rozpoczyna się w Łaźniach Lukács. Dowiadujemy się, że Sindbad chodził tu całe lato. Goście łaźni czytają czasopismo „Élet és Irodalom” [Życie i Literatura], Sindbad odwiedza kino Múvész, Teatr Józsefa Katony lub Radnótiego, biegający po Wyspie Małgorzaty budapeszteńczycy słuchają podczas joggingu muzyki na iPodzie, a Sindbad kiedyś bywał nawet na Sziget Festival. Dowiadujemy się również, jak bardzo Sindbad nienawidzi turystów, którzy przyjeżdżają do Budapesztu tylko po to, by objeść się zupa gulaszową i naleśnikami Gundela, słuchając przy tym cygańskiej muzyki. Z daleka omija ulicę Váci, plac Vörösmartyego, okolice Bazyliki i Wzgórze Zamkowe, preferuje raczej spacery po cmentarzu Farkasréti. Sindbad w opowiadaniu Vargi jest mężczyzną w średnim wieku, który czuje, że zaczyna się starzeć. Należy do kręgów inteligencji, choć ostatnimi czasy stracił zainteresowanie kulturą i chętniej spędza czas w towarzystwie dobrego gulaszu i wyrafinowanego wina. Po wizycie w Łaźniach Lukács szuka małej knajpki, cytując teksty Krúdyego gawędzi z kelnerem, wyraża opinie na temat niektórych potraw. Karta dań w restauracji nic się nie zmieniła od czasów Jánosa Kádára. Kelner poleca kapustę po szeklersku i indyka po kijowsku, ale danie to bardzo znudziło się już Sindbadowi, który radzi, aby zmienić jego nazwę na indyka po budapeszteńsku, ponieważ stał się już potrawą narodową. W końcu zamawia flaki,

\footnotetext{
15 Gulasz z turula, s. 26-27.

16 Tamże, s. 27.

17 Tamże, s. 28.

${ }^{18}$ K. VArga, Sindbad się starzeje, w: Pod dobra gwiazda, Kraków 2009, s. 316-334.
} 
ziemniaki posypane pietruszką, mizerię oraz, oczywiście, szprycera. W trakcie jedzenia rozprawia o tym, jak przygotować dobrego szprycera i jak należy rozmawiać z kobietami. Po spożyciu posiłku opanowuje go melancholijne poczucie sytości, które podobno nie jest rzadkością po odwiedzinach w węgierskiej restauracji. Po obiedzie wybiera się na spacer po cmentarzu Farkasréti. Tak Sindbad spędzał zwykle czas, ale pewnego dnia plan uległ zmianie i nasz bohater poszedł popływać do Łaźni Dagály. Zimna woda orzeźwiła jego ciało, czuł się tak, jakby całkowicie odmłodniał, próbował nawet trochę podbojów miłosnych, ale w efekcie poniósł sromotną klęskę. Po tej nieszczęsnej przygodzie odwiedził jednak znowu stare dobre Łaźnie Lukácsa. Opowiadanie poprzez wprowadzenie postaci starego czy też starzejącego się Sindbada, jak i pod względem treści nawiązuje do powieści Sándora Máraiego Sindbad powraca do domu. Na końcu opowiadania Vargi znajdują się uwagi autora, które oferują wyjaśnienie w związku z postacią Sindbada. Również i tutaj wspomina on powieść Máraiego, co zdradza, że już w tym momencie znane było mu to dzieło. Sindbad Vargi pojawia się jako współczesny nam bohater, a porównując z Gulaszem z turula i Bildungsroman, prawdopodobne wydaje się, że wyposażony został w liczne elementy autobiograficzne. Mimo wszystko Sindbad pozostaje bohaterem literackim, co widoczne jest szczególnie w scenie, w której bezskutecznie zaleca się do dziewczyny na plaży. Zastanawia się, czego też może uczyć się dziewczyna, czy może jest studentką hungarystyki, choć to niemożliwe, bo przecież już dawno by go rozpoznała.

Wpływ tradycji sindbadowskiej pojawia się w prozie Vargi nie tylko explicite poprzez wprowadzenie postaci Sindbada. Styl jego prozy naznaczony jest wieloma cechami, które przywodzą na myśl wspomnianą tradycję pisarską. Sa to zainteresowania gastronomiczne, połączenie pamięci i gastronomii, łaźnie jako ulubione miejsce, styl narracji skłonny do nostalgii i melancholii. Kompozycja asocjacyjna, długie dygresje i obszerne opisy również są cechami charakterystycznymi prozy Krúdyego. We wstępie biograficznym do monografii Máraiego jej autor, Mihály Szegedy-Maszák, nazywa Sándora Máraiego najbardziej autobiograficznym autorem węgierskiej literatury, gdyż w jego twórczości nierozerwalnie splatają się wątki autobiograficzne i fikcja ${ }^{19}$. Tendencje autobiograficzne widoczne są również u Krúdyego, u Vargi natomiast już od pierwszej jego powieści stanowią one ważny element z punktu widzenia interpretacji.

\footnotetext{
19 M. Szegedy-MaSzáK, Márai Sándor, Budapeszt 1991, s. 7.
} 


\section{3. „BÓG JEST OBECNY NAWET W GOTOWANEJ SZYNCE”20}

Mówienie o tradycyjnym związku gastronomii i literatury jest już truizmem. Nieprzemijającą aktualność tego tematu pod względem literackim i teoretycznym doskonale ilustruje przykład czasopisma literacko-kulturalnego „Alföld”, które we wrześniu 2007 roku poświęciło cały numer tematyczny powiązaniom literatury i gastronomii ${ }^{21}$. „Potrawy i napoje podniesione do rangi sztuki, literatury są niewyczerpanym zbiorem motywów i tematów” - pisze Tamás Tarján w przytoczonym tu szkicu ${ }^{22}$.

Potrawy oraz ich spożywanie mają w literaturze i sztuce znaczenie symboliczne. Z perspektywy semiotyki potrawa, jej przygotowanie, jak i spożycie interpretowane są w kategoriach znaków, czyli jako elementy komunikacji ${ }^{23}$. „Potrawy są nie tylko obiektami zaspokajającymi potrzeby fizjologiczne, funkcjonują one również jako nośniki znaczeń i wartości zakodowanych w społeczeństwie i kulturze" 24 . Znaczenia te jednak obowiązują tylko w danej społeczności, czego doskonałym przykładem jest to, że różnice kulturowe przejawiają się również w zwyczajach związanych z jedzeniem. „Każda kuchnia narodowa odwzorowuje kod kultury, której jest częścią, przyczyniając się tym samym do jej formowania” ${ }^{25}$. Dalej: „Przyjęcie i postępowanie według danej kultury kulinarnej zakłada powiązania w zakresie życia, myślenia i sposobu zachowania" ${ }^{26}$. W literaturze motyw gastronomiczny może pełnić różne funkcje: może brać udział w budowaniu akcji, stylu utworu, intertekstualności, może również wykorzystywać motywikę tożsamościową. Jest tak na przykład w opowiadaniu Móricza pt. Ebéd [Obiad]. Daje to również klucz do prozy Vargi, gdzie potrawy i rytuał ich spożywania ukazują rozwinięcie się jego własnej węgierskiej tożsamości na poziomie motywicznym. Węgierskie potrawy pojawiają się jako turystyczne banały, stereotypy, ale jednocześnie okazuje się, że narrator-bohater tak naprawdę bardzo lubi te dania. Jest wiernym wielbicielem restauracji i jadłodajni starego typu. Wiele takich restau-

\footnotetext{
${ }^{20}$ Cytat z książki Béli Hamvasa pt. Filozofia wina (Warszawa 2013). W polskim wydaniu fragment ten ukazał się w tłumaczeniu wolnym: „Oburzył się do żywego, kiedy zastąpiłem Boga pojęciem błogiej sytości, mając na myśli smak i zapach świątecznej szynki”.

21 „Alföld” 2007, nr 9.

22 T. TARJÁN, Itt enned, innod kell, „Alföld” 2007, nr 9, s. 116.

${ }^{23}$ K. Benyovszky, Irodalmi étlapok, „Alföld” 2007, nr 9, s. 105.

${ }^{24}$ Tamże.

25 Tamże.

26 Tamże.
} 
racji wymienia z nazwy, tworząc tak właściwie przewodnik gastronomiczny po Budapeszcie. Możemy przeczytać szczegółowe opisy tych miejsc, kart dań, potraw. Dowiadujemy się nawet, jaki jest prawdziwy węgierski kelner.

$\mathrm{Za}$ największego przedstawiciela nurtu gastronomicznego w węgierskiej literaturze tradycyjnie uważa się Gyulę Krúdyego. Motyw gastronomiczny obecny jest praktycznie w całej jego twórczości, ale szczególnego znaczenia nabiera on w latach dwudziestych, do tego okresu należą tzw. gyomornovellák („opowiadania żołądkowe”) oraz powieść Boldogult úrfikoromban [W mych świętej pamięci młodzieńczych latach]. W utworach tych jedzenie służy zazwyczaj tylko jako alibi dla długich wynurzeń metafizycznych. Poprzez jedzenie pisarz potrafi powiedzieć jeszcze więcej o losie swoich bohaterów ${ }^{27}$. Spotykamy się zarówno z opisami posilającego się człowieka, jak i potraw oraz sposobu ich przygotowania. Ta ostatnia kwestia często staje się zalążkiem dyskusji pomiędzy postaciami. Sceny spożywania posiłków zawsze obrazowane są jako rytuał ${ }^{28}$. „Nierzadko zdarza się, że opis rytuału zamawiania dań i napojów okazuje się bardziej obszerny i ciekawy, niż następujące po nim wydarzenia" ${ }^{29}$. Trudno znaleźć u Krúdyego bohaterów, którzy posilają się w otoczeniu rodziny, za miejsce spożywania posiłków służą zazwyczaj restauracje, karczmy, gospody, jako że jedzenie jest jednocześnie rytuałem towarzyskim. Tym samym bohaterowie uciekają $w$ te miejsca od swojej bezdomności ${ }^{30}$. W opowiadaniu zatytułowanym Isten veletek, ti boldog Vendelinek! [Bóg z Wami, szczęśliwi Vendelinowie!] Krúdy pisze, że warto odwiedzać raczej małe karczmy niż eleganckie restauracje, ponieważ w tych drugich ludzie nie jedzą w sposób naturalny.

Varga w opisach swoich wycieczek gastronomicznych po restauracjach wpisuje się w tradycje literackie związane z Krúdym. W nostalgicznym tonie wspomina i kontynuuje tradycje gastronomiczne węgierskiej literatury. Świadczy o tym również jego technika prozatorska, jako że oś narracji wyznaczają klimat, doświadczenia zmysłowe i wspomnienia. Poprzez opis gastronomii tworzy swoją własną tożsamość kulinarną. Wspominanie potraw jest dla niego równoznaczne ze wspominaniem węgierskiego życia, tak jak wspomnienia $\mathrm{z}$ dzieciństwa wiążą się z charakterystycznymi potrawami spożywanymi w trakcie jego wizyt na Węgrzech. Varga świadomie nawiązuje, a nawet

\footnotetext{
${ }^{27}$ L. FÜLÖP, Közelítések Krúdyhoz, Budapeszt 1986, s. 176.

28 Tamże, s. 189.

${ }^{29}$ Tamże, s. 190.

30 Tamże, s. 186.
} 
kilkakrotnie przywołuje najsłynniejszą scenę, w której gastronomia wiąże się ze wspomnieniami, a mianowicie magdalenki Prousta. „W dzieciństwie na Węgrzech najbardziej lubiłem zapach rozchodzący się z mieszkań koło godziny trzynastej, kiedy nakrywano do stołu. Słodka woń duszonych na smalcu warzyw, leczo, faszerowanej papryki, zapiekanki kartoflanej. Tanich, sycących, jednodaniowych posiłków, po których można już było nie jeść do końca dnia. Podawanych ze świeżym, białym chlebem, miękko moszczącym żołądek. Pamiętam na proustowski sposób te zapachy z ulic XIV dzielnicy, gdzie mieszkały zaprzyjaźnione z moim ojcem rodziny. Szczególnie dobrze pamiętam obiady u państwa Répów, mieszkających przy Újvidék tér" ${ }^{31}$. Jednakże warto tu znowu nawiązać do Krúdyego, ponieważ wszystkie potrawy występujące w ,opowiadaniach żołądkowych” odgrywają w historiach rolę zastępczą. W jego opowiadaniu Isten veletek, ti boldog Vendelinek! [Bóg z Wami, szczęśliwi Vendelinowie!] każde danie przywołuje jakieś wspomnienie, historię poprzez zasadę przyległości metonimicznej. „Wspominanie nie jest niczym innym, niż przywoływaniem utożsamianych ze sobą synekdoch metonimicznych z przeszłości poprzez podobieństwo w teraźniejszości”,32.

Jednak Varga nie jest jedynym zagranicznym pisarzem o węgierskich korzeniach, u którego pojawia się kwestia tożsamości kulinarnej. Ze względu na temat można tutaj wspomnieć o książce Viviane Chocas pt. Bazar magyar [Węgierski bazar], która ukazała się na Węgrzech w 2007 roku ${ }^{33}$. Autorka jest francuską dziennikarką pochodzącą z rodziny węgierskich emigrantów, relacjonowała transformację ustrojową na Węgrzech. Jej książka opowiada o stopniowym odkrywaniu na nowo węgierskich korzeni i tożsamości, ale szczególnie istotne jest to, że cała historia toczy się wokół węgierskiej gastronomii, potraw i zmysłów. Tytuły rozdziałów, tak samo jak u Vargi, przywołują węgierskie potrawy: pączek karnawałowy, gołąbki, salami, tokaj, kluseczki, białe wino, tort naleśnikowy. Rodzice nie nauczyli głównej bohaterki mówić po węgiersku, w domu zawsze rozmawiali ze sobą wyłącznie po francusku. „By przeżyć, zamordowali swój język” "34. Jedyne, co pozostało z ich węgierskiej tożsamości, to węgierskie potrawy, ponieważ „świat nie widział jeszcze czegoś takiego, by ustrój polityczny obalił kuchnię narodową" 35 .

31 Gulasz z turula, s. 7.

${ }^{32}$ L. SzILASI, Maggi, Étel által történó helyettesítés és evés által történó emlékezés Krúdy Gyula Isten veletek, ti boldog Vendelinek! címú novellájában, „Literatura” 2002, nr 3, s. 321.

${ }^{33}$ V. Chocas, Magyar bazár, Budapeszt 2007.

34 Tamże, s. 11.

35 Tamże. 


\section{4. „WĘGIER NIE JEST SZCZĘŚLIWY”, CZYLI SŁYNNA WĘGIERSKA MELANCHOLIA}

Przedstawiony w Gulaszu z turula obraz Węgier przesiąknięty jest nostalgią, melancholią i pragnieniem śmierci. Węgierska depresja jest $\mathrm{z}$ jednej strony faktem statystycznym, z drugiej zaś niezwykle rozprzestrzenionym za granicą powszechnym przeświadczeniem (według znanego powiedzenia: „Węgier weseli się płacząc"). Również w historii literatury odnaleźć można tradycję węgierskiej melancholii. Jeśli chcielibyśmy pozostać tylko przy przodkach literackich wspomnianych przez Vargę, już sam Krúdy pisał, że „Węgier nie jest szczęśliwy". W powieści Máraiego natomiast - który oczywiście nawiązuje do Krúdyego - możemy przeczytać, że „tylko Sindbad i ludzie jego pokroju mieli świadomość, że cały kraj jest pogrążony w smutku"36.

Wokół przysłowiowej nostalgii węgierskiej duszy Varga buduje przede wszystkim Gulasz z turula, melancholia w Bildungsroman ma już inny charakter. Według niego pojęcia „węgierskość” i „nostalgia” są nierozłączne. „Nostalgia jest fundamentem, na którym buduje się węgierska tożsamość. Nostalgia za czasami wielkości, choć zbyt często była to wielkość iluzoryczna. Trudno jednak w nieuleczalnym smutku za stratą zbudować tożsamość inną niż nieszczęśliwa" ${ }^{37}$. Uważa on, że nieodzowną podstawą węgierskiego bytu jest nostalgia. Wszędzie znajdują się wywołujące nostalgię kawiarnie, możemy zjeść w bufecie Nostalgia, kupować nostalgiczne pamiątki w przesiąkniętym wręcz nostalgią antykwariacie oraz podróżować do malowniczego Zakola Dunaju pociaggami wypełnionymi poczuciem nostalgii. Z wytęsknieniem myślimy o dawnych czasach wielkości, ale nie wiadomo, kiedy dokładnie ta wielkość była. Właściwy dla Węgrów jest mit starych dobrych czasów.

Winą za węgierską depresję Varga obarcza znaną z ciężkich potraw kuchnię węgierską. „Mnie zawsze po obfitym budapeszteńskim posiłku ogarniają: melancholia, tęsknota, smutek i zniechęcenie. [...] Jestem najedzony i nieszczęśliwy; dokonuję rachunku sumienia i jest to rachunek dziesięciokrotnie przekraczający kwotę, jaką muszę dać kelnerowi"38. Drugą przyczynę węgierskiej depresji znajduje w nieprzepracowanej żałobie historycznej. Tragedię

\footnotetext{
${ }^{36}$ S. MÁRAI, Sindbad powraca do domu, Warszawa 2008, s. 106.

37 Gulasz, z turula, s. 35.

38 Tamże, s. 22.
} 
węgierskiego losu widzi jednak również w tym, że Węgrom nie udało się uczynić ze swojej traumy historycznej sprawy o zasięgu światowym ${ }^{39}$.

W dwóch miejscach, w wątkach dotyczących historii wyraźnie czuć, że Varga patrzy na węgierską kulturę „oczyma Polaka”. W pierwszym tego typu fragmencie rzeczywiście dokonuje projekcji mesjanizmu na sytuację Węgier w związku z Széchenyim, nazywającym siebie samego antychrystem: „Węgrom i Polakom w kluczowych momentach historii brakowało antychrystów, którzy by ich uratowali” ${ }^{40}$. W drugim fragmencie natomiast padają następujące słowa: „Lista węgierskich klęsk łagodzi listę węgierskich przestępstw"41. Zdanie to jest bez wątpienia prawdą, której źródeł należy szukać w widocznej wśród Polaków potrzebie rozliczenia się z własnymi przewinieniami historycznymi, co we współczesnej literaturze polskiej jest obecnie ważnym i powracającym tematem.

W nawiązaniu do węgierskiej depresji Varga pisze także o skłonności Węgrów do popełniania samobójstwa. Wymienia postaci historyczne, gwiazdy, osobistości ze świata polityki i popkultury, którzy sami odebrali sobie życie. Nie uważa za przypadek również i tego, że nazywana hymnem samobójców piosenka Szomorú vasárnap (znana również jako Gloomy Sunday) też jest utworem węgierskim. „Historia węgierskiej kultury to historia samobójstwa. Odbieranie sobie życia jest nieodłącznym składnikiem, a właściwie konsekwencją węgierskiej nostalgii; nie da się wytrzymać tęsknoty nie wiadomo za czym - zamienia się ona w bezdenną depresję, prowadzącą do pozbawienia się życia"42.

W Bildungsroman właściwie wszystko przesiąknięte jest medytacją o śmierci i myślą o przemijaniu. Autor wyobraża sobie Góry Budzińskie jako ogromną nekropolię. Fizyczne starzenie się ojca jest pretekstem do długich rozważań na temat rozkładu ciała. Spojrzenie dostrzegające wszędzie śmierć i zmarłych przywodzi na myśl opowiadanie Krúdyego Érzelgös utazás [Podróż sentymentalna], w którym Dunajem spływają martwe ciała mężczyzn i kobiet. Zamyślony na brzegu Sindbad wchodzi do wody, by odnaleźć ciało zmarłej ukochanej, ale jednocześnie myśli o tym, że przy okazji może zapoznać się z samobójczyniami ${ }^{43}$. W Bildungsroman pojawia się osławiona wysoka liczba samobójstw na Węgrzech, ale plotki sąsiadów również często krążą wokół tego tematu. Można podejrzewać, że to właśnie tu należałoby

\footnotetext{
39 Tamże, s. 71.

40 Tamże, s. 52.

41 Tamże, s. 51.

42 Tamże, s. 76.

${ }^{43}$ Gy. KRÚDY, Érzelgốs utazás, w: Szindbád, Budapest 1975, http://mek.niif.hu/00700/00 760/html/04.htm\#39
} 
szukać korzeni melancholijnych Węgier przedstawionych w Gulaszu z turula, a nawet $\mathrm{i}$ to, że w rzeczywistości legenda ta służy autorowi za alibi do stawiania metafizycznych pytań. Varga odczuwa pociąg do tematyki śmierci, co jest w równym stopniu cechą charakterystyczną tego pisarza, jak i węgierskiej duszy. Melancholia jest elementem powracającym także w utworach o innej tematyce. Bohater wydanej również na Węgrzech książki pt. Aleja Niepodległości ${ }^{44}$ traci życie już w pierwszym zdaniu powieści. Natomiast bohater jego wcześniejszej powieści Nagrobek z lastryko ${ }^{45}$, spoglądając wstecz z perspektywy polskiej utopii i szykując się do samobójstwa, opowiada historię swojego życia oraz swojej rodziny.

\section{PODRÓŻ CZY POWRÓT DO DOMU?}

Można powiedzieć, że Varga przybył na Węgry jako obcokrajowiec i patrzy na miejscową kulturę jako obserwator z zewnątrz. Stosunki tam panujące zna jednak w podobnym stopniu jak miejscowi, dysponuje obszerną wiedzą na temat węgierskiej kultury i sytuacji w kraju. W rozdziałach swojej książki to on jest dla polskiego czytelnika przewodnikiem po różnych obszarach węgierskiej kultury. W tym celu wykorzystuje wszystkie możliwe środki, jeśli trzeba, szuka paraleli z Polską. Ze szczególnym upodobaniem nawiązuje do filmów i różnorodnych produktów popkultury. W jego pisarstwie pojawia się jednocześnie głos wyrażający zdziwienie z powodu doświadczenia obcości oraz pewności siebie fikcyjnego przewodnika. Wygląda na to, że węgierskie podróże Vargi powinniśmy interpretować częściowo jako powrót do domu. Spostrzeżenie to dodatkowo uzasadnia fakt, że podczas jego pobytu w Budapeszcie przyjeżdżający znajomi z Polski postrzegaja go jako gospodarza ${ }^{46}$.

Z Węgrami jednak łączy go nie tylko pochodzenie. Jak wynika z porównania Bildungsroman i Gulaszu z turula, obraz Węgier z jego dzieciństwa jest zupełnie inny niż ten, który został odkryty świadomie - i to właśnie ten drugi oznacza rzeczywiste ukształtowanie się węgierskiej tożsamości. Jeszcze większą uwagę zwraca on na motywy samodefiniowania się narodu węgierskiego, które są przede wszystkim wykorzystywane jako reprezentacja dla świata zewnętrznego i dlatego maja tak jednostronny i powierzchowny charakter. Varga dekonstruuje te

\footnotetext{
${ }^{44}$ K. VARGA, Aleja Niepodległości, Wołowiec 2010.

${ }^{45}$ K. VARGA, Nagrobek z lastryko, Wołowiec 2007.

${ }^{46}$ L. PÁlfalvi, Krzysztof Varga, s. 88.
} 
motywy, ale stworzony przez niego obraz także jest jednostronny. Możemy określić to nawet jako zburzenie mitu narodowego, ale o tym, że autor nie tylko krytykuje, doskonale świadczy jego entuzjastyczny opis regionu winiarskiego Villány w Gulaszu z turula oraz zakończenie dziennika z Peczu.

W jego wspomnieniach oraz podczas odbywanych w czasie teraźniejszym podróżach części odnoszące się do Polski płynnie przechodzą w te związane z Węgrami i vice versa, co wskazuje na to, że tożsamość narratora jest cały czas w ruchu, nieustannie się kształtuje. Topos podróży w literaturze wyznacza paralelę pomiędzy podróżą fizyczną i wewnętrzną podróżą duchową, a spotkanie z obcością zmienia konstrukcję ,ja”. Nie będzie chyba przesadą stwierdzenie, że dla Vargi podróże po Węgrzech są podróżami kształtującymi tożsamość, pomimo iż w Gulaszu z turula pozornie nie ma o tym mowy, a bohater Bildungsroman zdawałoby się wcale się nie rozwija. Tytuł powieści odnosi się do gatunku literackiego, w którego centrum znajduje się główny bohater i zachodzące w nim kształtowanie się charakteru lub wkraczanie w dorosłość. Jednak bohater Vargi na próżno rusza w drogę, by powrócić w miejsca związane z dzieciństwem - najwyraźniej podróż ta nie wywiera na niego żadnego wpływu. Możemy przeczytać, że „Ta historia zaczyna się nigdzie i tam też się kończy" "47. Zakończenie powieści stawia pod znakiem zapytania znaczenie, a nawet zasadność całej historii. „Cóż jest dziwnego w historii, której bohaterowie, jeżeli nawet przez chwilę intrygujący, nigdy nie przejdą do legendy wojennej, podróżniczej, miłosnej ani jakiejkolwiek innej, ponieważ nie będzie już nigdy więcej żadnych legend" ${ }^{\text {"48 }}$. Tożsamość narratora rodzi się w głównej mierze nie $\mathrm{w}$ obrębie pojedynczych utworów, lecz w ich wzajemnych powiązaniach, w powracajacych motywach, sceneriach i tematach.

\section{BIBLIOGRAFIA}

ANGYALOSI G.: A pastiche mint interpretáció, „Literatura” 1986, nr 1-2.

BENYOVSZKY K.: Irodalmi étlapok, „Alföld” 2007, nr 9.

BODNÁr Gy.: A „mese”, a novellaciklus és a Szindbád, „Literatura” 1986, nr 1-2.

CHOCAS V.: Magyar bazár, Budapeszt 2007.

FÁBRI A.: Ciprus és jegenye, Budapeszt 1978.

FÁBRI A.: „Egykor regényhő́s voltam...”, Az irodalom kultusza Krúdy Gyula múveiben, „Holmi” $2000, \mathrm{nr} 6$.

\footnotetext{
${ }^{47}$ Bildungsroman, s. 139.

48 Tamże, s. 142.
} 
FÜLÖP L.: Közelítések Krúdyhoz, Budapeszt 1986.

HAMvas B.: Filozofia wina, tłum. T. Olszański, Warszawa 2013.

KERESZTES G.: Mi legyen az ulánusok helyett?, „Élet és Irodalom” 2005, nr 11.

KRÚDY Gy.: Miasto uśpionych kobiet, tłum. E. Cygielska, T. Worowska, Warszawa 2019.

KRÚDY Gy.: Sindbad, tłum. A. Nawrocki, Warszawa 1988.

MÁrAI S.: Sindbad powraca do domu, tłum. T. Worowska, Warszawa 2008.

NAGY P.: Huszárik Zoltán: Szindbád, „Filmvilág” 1971, nr 23.

PÁlfalvi L.: Krzysztof Varga és a magyar-lengyel haikio-élmény, „Kalligram” 2012, nr 9.

SZEGEDY-MASZÁK M.: Márai Sándor, Budapeszt 1991.

SZILASI L.: Maggi, Étel által történő helyettesítés és evés által történő emlékezés Krúdy Gyula Isten veletek, ti boldog Vendelinek! címú novellájában, „Literatura” 2002, nr 3.

TARJÁN T.: Itt enned, innod kell, „Alföld” 2007, nr 9.

\title{
MOTYWIKA TOŻSAMOŚCI W TEKSTACH KRZYSZTOFA VARGI O TEMATYCE WĘGIERSKIEJ
}

\author{
St r e s z c z e n i e
}

Artykuł poświęcony jest problematyce tożsamości w utworach Krzysztofa Vargi o tematyce węgierskiej. Narracja w prozie autora Gulaszu z turula łączy w sobie daleko posunięty krytycyzm i ironię z nostalgicznym obrazem życia codziennego i kultury. Szczegółowe analizy sztuki prozatorskiej Vargi ukazują pisarza jako świadomego i jednocześnie uważnego obserwatora węgierskiej rzeczywistości, który obnaża kolejne elementy składowe narodowych mitów i symboli, a jednocześnie ujawnia głębokie źródła własnej tożsamości.

Słowa kluczowe: Krzysztof Varga; tożsamość; Węgry; narracja.

\section{MOTIFS OF IDENTITY IN THE HUNGARY-THEMED TEXTS BY KRZYSZTOF VARGA}

\section{$\mathrm{S} \mathrm{u} \mathrm{m} \mathrm{m} \mathrm{a} \mathrm{r} \mathrm{y}$}

This article discusses the issue of identity in Krzysztof Varga's works centred on Hungarian themes. The narrative in the prose of the author of Gulasz z Turula [Turul Goulash] combines far-reaching criticism and irony with a nostalgic picture of everyday life and culture. Detailed analyses of Varga's prose show that the writer is a conscious and simultaneously attentive observer of Hungarian reality, who exposes successive components of national myths and symbols, and at the same time reveals the deep sources of his own identity.

Key words: Krzysztof Varga; identity; Hungary; narration. 